\title{
COGNITIVE LINGUISTICS
}

EDITOR-IN-CHIEF

Dagmar S. Divjak

University of Birmingham, UK

CONSULTING EDITOR FOR THEORY

John Newman

University of Alberta, Canada

Monash University, Clayton, Australia
CONSULTING EDITOR FOR

METHODOLOGY

Petar Milin

University of Birmingham, UK

EDITORIAL ASSISTANT

Dagmar Hanzlíková

E-mail: cogling@degruyter.com

\section{ASSOCIATE EDITORS}

Martin Hilpert

Université de Neuchâtel, Switzerland

Zoltán Kövecses

Eötvös Loránd University, Budapest,

Hungary

Karin Madlener-Charpentier

University of Basel, Switzerland

Benedikt Szmrecsanyi

KU Leuven, Belgium

Sherman Wilcox

University of New Mexico, USA

\section{DE GRUYTER MOUTON}




\section{EDITORIAL BOARD}

Antonio Barcelona

University of Cordoba, Spain

Paul Chilton

Lancaster University, UK

William Croft

University of New Mexico at

Albuquerque, USA

Ewa Dabrowska

University of Birmingham, UK

Holger Diessel

University of Jena, Germany

Ad Foolen

Radboud University, The Netherlands

Dirk Geeraerts

University of Leuven, Belgium

Raymond W. Gibbs

University of California at Santa Cruz, USA

Stefan Th. Gries

University of California at

Santa Barbara, USA

Lynn Hou

University of California at Santa

Barbara, USA

Tuomas Huumo

University of Turku, Finland

Iraide Ibarretxe Antuñano

University of Zaragoza, Spain

Seizi Iwata

Kansai University, Japan

Vsevolod Kapatsinski

University of Oregon, USA
Ronald W. Langacker

University of California at San Diego, USA

Jeannette Littlemore

University of Birmingham, UK

Francisco J. Ruiz de Mendoza Ibáñez

Universidad de La Rioja, Spain

Irene Mittelberg

RWTH Aachen University, Germany

Klaus-Uwe Panther

University of Hamburg, Germany

Fey Parrill

Case Western Reserve University, USA

Frank Polzenhagen

University of Koblenz-Landau, Germany

Sally Rice

University of Alberta, Canada

Hans Joerg Schmid

Ludwig Maximilian University

of Munich, Germany

Dingfang Shu

Shanghai International Studies

University, China

Kari Sullivan

University of Queensland, Australia

Javier Valenzuela

University of Murcia, Spain

Arie Verhagen

Leiden University, The Netherlands

Jörg Zinken

University of Portsmouth, UK

Jordan Zlatev

Lund University, Sweden 
ABSTRACTED/INDEXED IN Baidu Scholar · Cabell's Directory · Chemical Abstracts Service (CAS): CAplus; SciFinder · CNKI Scholar (China National Knowledge Infrastructure) · CNPIEC: cnpLINKer . Dimensions · EBSCO (relevant databases) - EBSCO Discovery Service · Engineering Village · Genamics JournalSeek · Google Scholar · Inspec · Japan Science and Technology Agency (JST) · J-Gate · Journal Citation Reports/Science Edition · JournalGuide · JournalTOCs · KESLI-NDSL (Korean National Discovery for Science Leaders) · Mathematical Reviews (MathSciNet) · Microsoft Academic · Naviga (Softweco) · Primo Central (ExLibris) · ProQuest (relevant databases) · Publons · QOAM (Quality Open Access Market) · ReadCube · Reaxys · SCImago (SJR) · SCOPUS · Sherpa/ RoMEO - Summon (Serials Solutions/ProQuest) · TDNet · TEMA Technik und Management · Ulrich's Periodicals Directory/ulrichsweb · WanFang Data - Web of Science: Current Contents/Engineering, Computing, and Technology; Current Contents/Physical, Chemical and Earth Sciences; Science Citation Index Expanded - WorldCat (OCLC) · Zentralblatt Math (zbMATH)

The publisher, together with the authors and editors, has taken great pains to ensure that all information presented in this work reflects the standard of knowledge at the time of publication. Despite careful manuscript preparation and proof correction, errors can nevertheless occur. Authors, editors and publisher disclaim all responsibility for any errors or omissions or liability for the results obtained from use of the information, or parts thereof, contained in this work.

ISSN 0936-5907 · e-ISSN 1613-3641

All information regarding notes for contributors, subscriptions, Open access, back volumes and orders is available online at www.degruyter.com/view/j/cogl

RESPONSIBLE EDITOR Dagmar Divjak, Department of Modern Languages \& Department of English Language and Linguistics, University of Birmingham, Edgbaston, Birmingham B15 2TT, UK. E-mail: cogling@degruyter.com

JOURNAL MANAGER Claudia Hill, De Gruyter, Genthiner Straße 13, 10785 Berlin, Germany, Tel.: +49(0)30 26005 - 172, Fax: +49 (0)3026005 - 250, E-mail: claudia.hill@ degruyter.com

RESPONSIBLE FOR ADVERTISEMENTS Claudia Hill, De Gruyter, Genthiner Straße 13, 10785 Berlin, Germany, Tel.: +49 (0)30 26005 - 170, E-mail: anzeigen@ degruyter.com

(C) 2021 Walter de Gruyter GmbH, Berlin/Boston

TYPESETTING TNQ Technologies, Chennai, India

PRINTING Franz X. Stückle Druck und Verlag e.K., Ettenheim

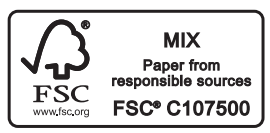




\section{Contents}

\section{Research articles}

Ewelina Wnuk and Yuma Ito

The heart's downward path to happiness: cross-cultural diversity in spatial metaphors of affect 195

Yu Fang and Haitao Liu

Predicting syntactic choice in Mandarin Chinese: a corpus-based analysis of ba sentences and SVO sentences -219

Rosa Vallejos and Hunter L. Brown

Locative construals: topology, posture, disposition, and perspective in Secoya and beyond -251

Lucia Busso, Florent Perek and Alessandro Lenci

Constructional associations trump lexical associations in processing valency coercion -287

Antje Endesfelder Quick, Ad Backus and Elena Lieven

Entrenchment effects in code-mixing: individual differences in German-English bilingual children — 319 